\title{
Dendritic and Axonal Targeting of Type 5 Metabotropic Glutamate Receptor Is Regulated by Homer1 Proteins and Neuronal Excitation
}

\author{
Fabrice Ango, ${ }^{1}$ Jean-Philippe Pin, ${ }^{1}$ Jian Chen Tu, ${ }^{2}$ Bo Xiao, ${ }^{2}$ Paul F. Worley, ${ }^{2}$ Joel Bockaert, ${ }^{1}$ and \\ Laurent Fagni ${ }^{1}$
}

${ }^{1}$ Centre National de la Recherche Scientifique UPR9023, Mécanisme Moléculaires des Communications cellulaires, 34094 Montpellier Cedex 5, France, and 2Department of Neuroscience, The Johns Hopkins University School of Medicine, Baltimore, Maryland 21205

The physiological actions of neurotransmitter receptors are intimately linked to their proper neuronal compartment localization. Here we studied the effect of the metabotropic glutamate receptor (mGluR)-interacting proteins, Homer1a, b, and c, in the targeting of mGluR5 in neurons. We found that mGluR5 was exclusively localized in cell bodies when transfected alone in cultured cerebellar granule cells. In contrast, mGluR5 was found also in dendrites when coexpressed with Homer1b or Homer1c, and in both dendrites and axons when cotransfected with Homer1a. In dendrites, cotransfected mGluR5 and Homer1b/c formed clusters that colocalized with the synaptic marker synaptophysin. Interestingly when transfected alone, the Homer proteins were also translocated to neurites but did not form such clusters. Depolarization of the neurons with a mixture of ionotropic gluta- mate receptor agonists, NMDA and kainate, or potassium channel blockers, tetraethylammonium and 4-aminopyridine, induced transient expression of endogenous Homer1a and persistent neuritic localization of transfected mGluR5 even long after degradation of Homer1a. These results suggest that Homer1a/b/c proteins are involved in the targeting of mGluR5 to dendritic synaptic sites and/or axons and that this effect can be regulated by neuronal activity. Because the activity-dependent effect of endogenous Homer1a was also long-lasting, the axonal targeting of mGluR5 by this protein is likely to play an important role in synaptic plasticity.

Key words: mGluR; Homer; targeting; synapse; cerebellar granule cells; transfection; immediate early gene
The group I $\mathrm{G}_{\mathrm{q}}$-protein-coupled glutamate receptors, metabotropic glutamate receptor 1 (mGluR1) and mGluR5 play important roles in neuronal development (Ryo et al., 1993; Catania et al., 1994; Van den Pol et al., 1994; Kano et al., 1997), synaptic plasticity (Anwyl, 1999; Bortolotto et al., 1999), and learning and memory (Aiba et al., 1994; Conquet et al., 1994; Lu et al., 1997). These receptors are located mostly in dendritic spines (Baude et al., 1993; Nusser et al., 1994; Lujan et al., 1996; Shigemoto et al., 1996), but some (probably mGluR5) are also distributed on glutamatergic nerve terminals (Gereau and Conn, 1995; Manzoni and Bockaert, 1995; Romano et al., 1995; Cochilla and Alford, 1998; RodriguezMoreno et al., 1998; Sistiaga et al., 1998). Postsynaptic group I mGluRs regulate neuronal excitability by inhibiting or activating $\mathrm{K}^{+}$channels (Chavis et al., 1998; Fiorillo and Williams, 1998; Anwyl, 1999). Also, cross-talk between mGluR5 and NMDA receptors (Yu et al., 1997; Alagarsamy et al., 1999) may be important in controlling long-term potentiation (LTP) (Anwyl, 1999). Presynaptic group I mGluRs, likely mGluR5, can either potentiate or inhibit glutamate release, depending on the ambient glutamate concentration (Herrero et al., 1998; Rodriguez-Moreno et al., 1998). Therefore, the precise amount of mGluR5 protein that is

Received Aug. 3, 2000; revised Sept. 5, 2000; accepted Sept. 11, 2000.

This work was supported by grants from the Centre National de la Recherche Scientifique, the European Community [Biomed2 (BMH4-CT96-0228) and Biotech2 (BIO4-CT96-0049) programs], the "action initiative" "Physique et Chimie du Vivant" from the French government (PCV97-115), Fondation pour la Recherche Médicale, Association Française contre les Myopathies, and Bayer company. F.A. is supported by Synthélabo-Biomoléculaire (Strasbourg). P.F.W. is supported by grants from the National Institute on Drug Abuse and the National Institute of Mental Health. We thank Dr. Bernard Mouillac and Carmelo Romano for the gift of the anti-c-Myc and anti-mGluR5 antibodies, respectively, Drs. Cécile Joly and Agnes Hémar for their help in the construction of the tagged mGluR5 expression plasmids, and Carine Becamel for her help in the Western blotting experiments.

Correspondence should be addressed to Dr. Fagni, Centre National de la Recherche Scientifique UPR9023, Mécanisme Moléculaires des Communications cellulaires, 141 rue de la Cardonille, 34094 Montpellier Cedex 5, France. E-mail: fagni@ccipe. montp.inserm.fr.

Copyright (C) 2000 Society for Neuroscience $0270-6474 / 00 / 208710-07 \$ 15.00 / 0$ targeted to either the presynaptic or postsynaptic elements appears to be crucial for a proper control of glutamatergic transmission.

The C-terminal intracellular tail of mGluR5 has been shown to interact with the so-called family of Homer proteins (Brakeman et al., 1997; Kato et al., 1998; Xiao et al., 1998). Three genes encoding Homer proteins, homer1-3, have been characterized. These proteins consist of an N-terminal domain homologous to the EVH1 domain of the Ena/VASP family of proteins and a C-terminal domain containing a leucine zipper motif responsible for their dimerization (Kato et al., 1997; Xiao et al., 1998). The splice variant Homer1a is the only isoform lacking of this $\mathrm{C}$-terminal leucine zipper and as such cannot dimerize. Interestingly, Homer1a is the product of an immediate early gene (IEG), the expression of which is induced during intense neuronal activities such as those required for induction of LTP or convulsive seizures (Brakeman et al., 1997; Kato et al., 1997). The EVH1 domain of Homer1 proteins interacts with a PPXXFR motif found in the C terminus of the mGluR1a, mGluR5a, $\mathrm{mGuR} \mathrm{b}, \mathrm{IP}_{3}$, and ryanodine receptors (Tu et al., 1998).

Three functions have been proposed for Homer proteins. First, Homer1 dimers optimize group I mGluR $\mathrm{Ca}^{2+}$ responses in neurons (Tu et al., 1998). Second, Homer1 interacts with the Shank/ GKAP/PSD-95/NMDA receptor complex (Naisbitt et al., 1999; Tu et al., 1999). Third, Homer1b in HeLa cells is responsible for retention of mGluR5 into endoplasmic reticulum pools (Roche et al., 1999), whereas Homer 1a in human embryonic kidney (HEK) 293 cells increases cell surface expression of mGluR1a (Ciruela et al., 1999). In the present study we describe a fourth function for Homer1 proteins: redistribution of mGluR5 in dendrites and/or axons, depending on the type of Homer1 variant that is expressed.

\section{MATERIALS AND METHODS}

Cell cultures. Primary cultures of cerebellar and striatal cells were prepared from newborn and fetal mice, respectively, as previously described (Weiss et al., 1986; Van-Vliet et al., 1989). Cerebellar cultures were grown in 25 $\mathrm{mm} \mathrm{KCl}$ to improve neuronal survival. One-week-old cerebellar and striatal cultures contained $95 \%$ neurons and $5 \%$ glial cells. Neurons versus 
non-neuronal cells were identified on the basis of morphology (Ango et al., 1999).

Two different protocols were used to induce expression of endogenous Homer1a in cerebellar cultures. The first protocol consisted of a TEA (20 $\mathrm{mm})+4$-AP (20 mM) exposure, which blocked $90 \%$ of the macroscopic voltage-activated $\mathrm{K}^{+}$current (data not shown). In the second protocol cerebellar neurons were exposed to a mixture of NMDA $(100 \mu \mathrm{M})+\mathrm{KA}$ $(100 \mu \mathrm{M})$ and then maintained in the presence of the NMDA receptor antagonist MK801 (1 $\mu \mathrm{M})$, after wash-out of the agonists, to avoid excitotoxic effects caused by this treatment. No toxicity was observed within $5 \mathrm{~d}$ after either one of these treatments.

Plasmids and transfections. Expression plasmids containing mGluR5a tagged at its $\mathrm{N}$ - or $\mathrm{C}$ terminus with either the hemagglutinin (HA) or Myc epitopes, were constructed as previously described (Ango et al., 1999) These epitope-tagged mGluR5 proteins were verified to be functionally expressed in HEK 293 cells (data not shown), like the wild-type mGluR5a in neurons (Ango et al., 1999). Construction of the mGluR5 mutants (mGluR5 $\Delta=$ N887stop, P1125E, P1127A and F1128R) were described previously (Mary et al., 1998; Tu et al., 1998). In some experiments, the epitope-tagged-mGluR5 was cotransfected with the green fluorescent protein (GFP) expression plasmids (pEGFP-N1; Clontech, Cambridge, UK) as previously described (Ango et al., 1999).

Transfection and immunocytochemistry. Cultures were transfected by means of the cationic lipid Transfast (Promega, Madison, WI), as previously described (Ango et al., 1999). Seven days (or 2 weeks when stated in the text) after transfection they were fixed in a PBS solution containing 4\% paraformaldehyde and $0.1 \mathrm{M}$ glucose and then permeabilized with $0.05 \%$ Triton X-100. The primary antibodies used here were: a rabbit antiHomer1 directed against a peptide common to all Homer1 splice variants (Brakeman et al., 1997), an anti-Homer2 and anti-Homer3 antibodies (Xiao et al., 1998) used at a 1:1000 dilution, a rabbit polyclonal anti-HA antibody (Molecular \& Biological Laboratories, Nagoya, Japan; 1:300), a mouse monoclonal anti-Myc antibody (gift from B. Mouillac; 1:300), a mouse polyclonal anti-MAP-2 antibody (Sigma, St. Louis, MO; 1:200), a mouse polyclonal anti-tau-1 antibody (Sigma; 1:100), and a rabbit polyclonal anti-synaptophysin antibody (1:100). The secondary antibodies were a mouse anti-rabbit FITCconjugated (Jackson ImmunoResearch, West Grove, PA; 1:200) and a goat Texas Red-conjugated anti-mouse (Jackson ImmunoResearch; catalog \#115075-146; 1:1000) IgG antibodies. The following experiments attested to the specificity of anti-HA and anti-Myc antibodies in our experimental conditions. In nontransfected cultures, no HA or Myc immunolabeling was observed. Also, in cultures cotransfected with HA-mGuR5 or Myc-mGluR5 and GFP, all HA- or Myc-positive neurons also expressed GFP.

After immunoreactions, cultures were mounted for observation on an upright Axiophot 2 Zeiss microscope equipped to visualize FITC and Texas Red immunofluorescence. The fluorescent-cell counting procedure was replicated in three different dishes from a same culture and on at least three different cultures. Images were acquired by using a Hamamatsu CCD camera and digitized by means of the Photoshop 5.0 software (16 bits, $736 \times 509$ pixels per image)

The intensity of HA immunolabeling was measured in the cell body of HA-mGluR5-transfected neurons by using the NIH Image, version 1.62 program (Wayne Rasband). Total fluorescence of the cell body area was determined and expressed as fluorescence density on a linear relative scale of 0 to 250 and in nonsaturating condition of the camera. The fluorescence density values were then averaged and expressed as percentage of mean fluorescence density obtained on neurons transfected with HA-mGluR5 alone.

Western blots were performed as follows. Neuronal cultures were homogenized using a glass Teflon poter in lysis buffer [Tris- $\mathrm{HCl} 50 \mathrm{~mm}$ EDTA $1 \mathrm{~mm}$, leupeptin $(10 \mu \mathrm{g} / \mathrm{ml})$, benzamidine $(100 \mu \mathrm{g} / \mathrm{ml})$, aprotinin $(10 \mu \mathrm{g} / \mathrm{ml})$, and antipain $(20 \mu \mathrm{g} / \mathrm{ml})]$. The particulate and soluble fractions were recovered after centrifugation $(40,000 \times g, 30 \mathrm{~min})$. Proteins were sampled $(80 \mu \mathrm{g})$ and solubilized with Laemmli buffer before separation in SDS-PAGE $7.5 \%$ acrylamide gel and transfer on a nitrocellulosic membrane (Amersham, Arlington Heights, IL). The membrane was exposed to the same anti-Homer1 primary antibodies (1:1000) as those used for immunofluorescence experiments (see above) and then to a secondary goat anti-rabbit antibody coupled to peroxidase (Pierce, Bezons, France; 1:4000). Protein immunolabeling was then revealed using standard chemiluminescence technique (ECL; Amersham, Saclay, France).

\section{RESULTS}

\section{Constitutive expression of Homer1 in cultured striatal, but not cerebellar neurons}

Homer1 has been reported to be widely expressed in the mammalian CNS, including striatum, but has not been detected in the cerebellar granule cell layer (Xiao et al., 1998). In agreement with this in vivo observation, Western blots and immunofluorescence experiments revealed that 1 -week-old cultured cerebellar granule cells did not express Homer1 proteins (Fig. 1A,C), whereas 1-weekold cultured striatal neurons expressed Homer1b/c (Fig. 1B,D). In striatal neurons, Homer1 immunostaining was distributed in both soma and neurites (Fig. 1D).
Expression of Homer2/3 proteins was also examined in these cultures. Cerebellar granule cells strongly expressed Homer3, mainly in the cell body, and weakly expressed Homer2. In contrast, Homer 2 but not Homer3 proteins were detected in cultured striatal neurons (data not shown).

\section{The presence of Homer1 was required for neuritic localization of mGluR5}

Seven days after transfection of N-terminal HA-tagged mGluR5a (HA-mGluR5) in our cultured cerebellar granule cells, the HA immunostaining was restricted to the soma with no detectable labeling in the processes (Table 1, Fig. $1 G$ ). The absence of neuritic HA immunolabeling was not attributable to absence of viable neurites, as evidenced by neuritic expression of GFP in the same neurons (Fig. $1 H$ ). In contrast to cerebellar neurons, HA-mGluR5 was found in both cell bodies and neurites of striatal neurons (64 of 64 neurons; Fig. $1 F$ ). Similar data were obtained with Myc-tagged
A Cerebellum
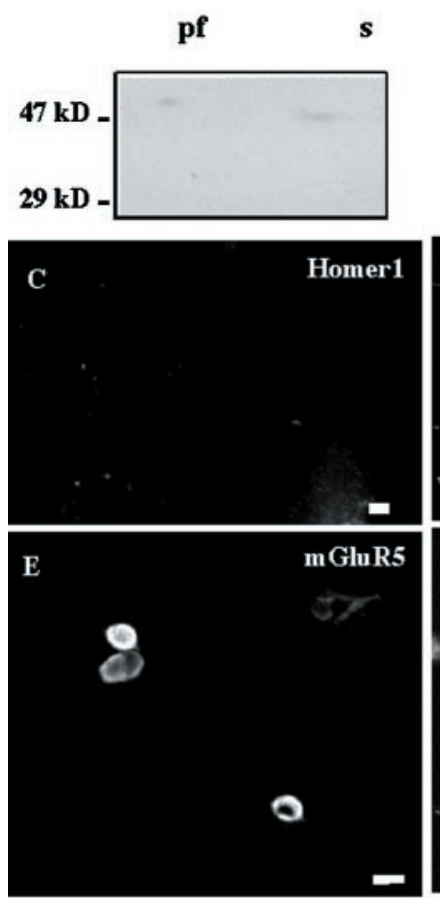

\section{B Striatum}
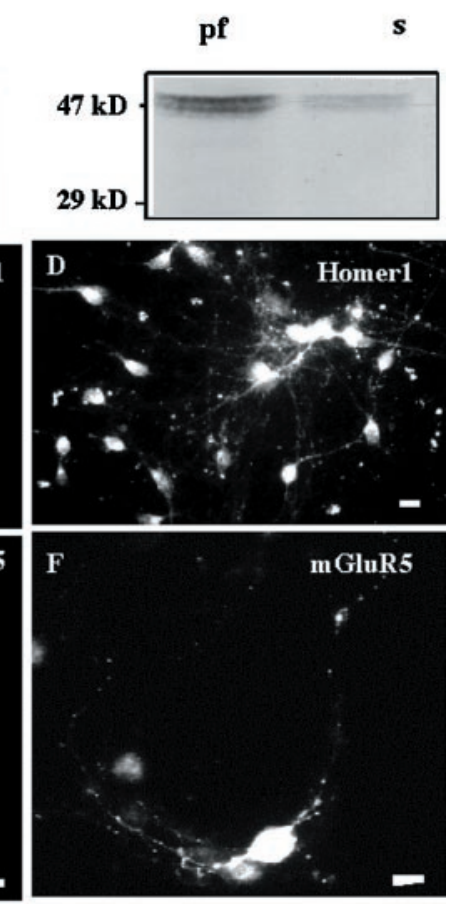

Cerebellum
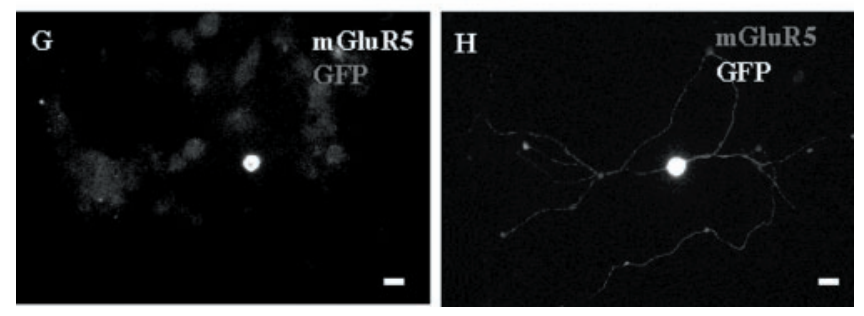

Figure 1. Differential expression of native Homer1 and transfected mGluR5 proteins in striatal and cerebellar cultures. $A$, Western blot obtained from a 1 -week-old cerebellar culture. The $29 \mathrm{kDa}$ calibration mark is the apparent molecular weight of the Homer1a protein. Homer1b/c isoforms display apparent molecular weights of $47 \mathrm{kDa} . p f$, Particulate fraction; $s$, soluble fraction. Similar results were obtained in a second independent experiment. $B$, Same legend as in $A$, but from a 1 -week-old striatal culture. Note the presence of Homer1b/c (47 kDa band). $A$ and $B$ were obtained from a same gel. $C$, Absence of Homer1 immunostaining in a 1-week-old cerebellar culture. $D$, Homer1a immunostaining in a 1-week-old striatal culture. $E, F, \mathrm{HA}-\mathrm{mGluR} 5$ immunostaining with anti-HA antibody in transfected cerebellar granule cell $(E)$ and striatal neuron $(F)$. $G, H$, Same cerebellar granule cell cotransfected with HA-mGluR5 and GFP. G, HA immunostaining; $H$, GFP fluorescence. In this and all the following figures, scale bars represent $10 \mu \mathrm{m}$. 
Table 1. Homer1a protein triggers localization of mGluR5 to the neurites of cultured cerebellar granule cells

\begin{tabular}{llcl} 
Transfected plasmids & $\begin{array}{l}\text { Labeled } \\
\text { cell bodies }\end{array}$ & $\begin{array}{l}\text { Labeled } \\
\text { neurites }\end{array}$ & $\begin{array}{l}\text { Number } \\
\text { of neurons }\end{array}$ \\
\hline $\begin{array}{l}\text { mGluR5 } \\
\text { mGluR5 + Homer1a }\end{array}$ & 320 & 13 & 320 \\
$\begin{array}{l}\text { C-term deleted mGluR5 + } \\
\text { Homer1a }\end{array}$ & 223 & 223 & 223 \\
$\begin{array}{l}\text { P1125E mGluR5 + } \\
\quad \text { Homer1a }\end{array}$ & 85 & 0 & 85 \\
$\begin{array}{l}\text { P1128R mGluR5 + } \\
\text { Homer1a } \\
\text { mGluR5 + induced } \\
\quad \text { Homer1a }\end{array}$ & 65 & 0 & 65 \\
\end{tabular}

Cerebellar granule cells displaying positive mGluR5 immunolabeling in cell body and/or neurites were counted, and their number was reported in each corresponding column.

mGluR5, and with Myc and HA epitopes being positioned at either $\mathrm{N}$ or $\mathrm{C}$ terminus of mGluR5 (data not shown).

Because striatal but not cerebellar neurons naturally expressed Homer1b/c, it was tempting to speculate that these proteins were necessary for the localization of mGluR5 in neurites. Indeed, when cotransfected in cultured cerebellar granule cells, Myc-Homer1b (41 of 43 cerebellar neurons; Fig. 2B) and HA-mGluR5 (91 of 91 neurons; Fig. $2 C$ ) were colocalized and displayed punctate pattern of distribution in neuritic processes, similar to that of HA-mGluR5 transfected in striatal neurons (Fig. $1 F$ ), which constitutively expressed Homer1b/c (Fig. 1B,D). When transfected alone, MycHomer1b was also located in both cell bodies and neurites but did not display such punctate distribution (100 of 100 neurons; Fig. $2 A$ ). This suggested that Homer1b was responsible for the mGluR5 localization in neurites and that its coexpression with Homer1b resulted in the formation of mGluR5-Homer1b clusters. Similar data were obtained with transfected Myc-Homer1c (data not shown).

Like Myc-Homer1b, Myc-Homer1a, which lacks of C-terminal leucine zipper domain, was detected in both soma and neurites of granule cells, whether it was transfected alone (98 of 100 neurons; Fig. $2 D$ ) or in combination with HA-mGluR5 (223 of 223 neurons; Fig. 2E). Therefore not only Homer1b, but also Homer1a, which does not dimerize, allowed the localization of mGluR5 in both soma and neurites. However, in contrast to the clear punctate neuritic distribution found with Myc-Homer1b (Fig. 2B,C), a more uniform distribution was observed when HA-mGluR5 was coexpressed with Myc-Homer1a (Fig. 2E,F). Thus, the C-terminal coiled-coil domain of Homer1b, which is necessary for its dimerization (Xiao et al., 1998), was required for the clustering of Homer1b and mGluR5 in neuritic processes.

It could be argued that the presence of HA-mGluR5 in the neurites observed in Myc-Homer1-expressing cells resulted from overexpression of the receptor in the cell body and diff usion of the protein to the neuritic processes. This was probably not the case because the levels of HA-mGluR5 immunofluorescence in the cell bodies of transfected granule cells were not significantly different whether the receptor was transfected alone $(100 \pm 2$ relative fluorescence density; $n=10$ ) or cotransfected with Homer1a $(102 \pm 1 ; n=10)$ or Homer1b $(95 \pm 4 ; n=10)$.

\section{Direct interaction between mGluR5 and Homer1 was required for the neuritic localization of the two proteins}

The Homer recognition sequence in mGluR5 is PPSPFR (from P1124 to R1129; italics are residues critical for Homer binding) located 45 residues before the C-terminal end ( $\mathrm{Tu}$ et al., 1998). Our data indicate that this sequence is essential for the proper localization of mGluR5 induced by Homer 1 proteins. Three epitope-tagged mGluR5 mutants, which have been previously char-
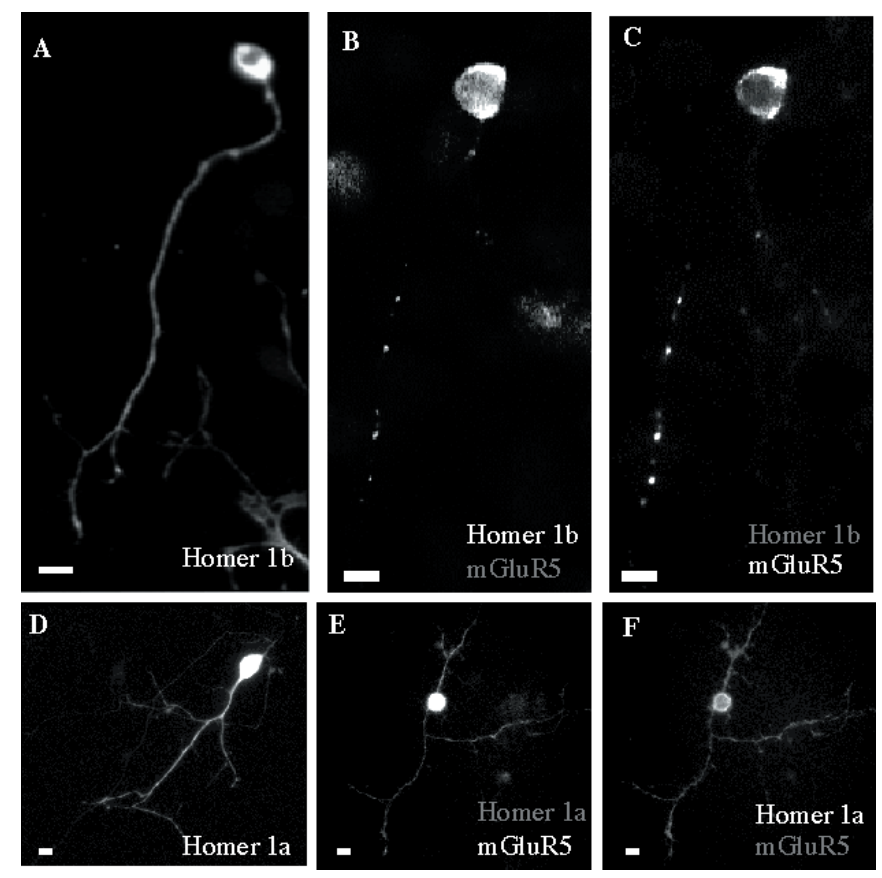

Figure 2. Neuritic localization of mGluR5 in cerebellar granule cells in the presence of Homer1a or Homer1b. A, Cerebellar neuron transfected with Myc-Homer1b and immunolabeled with anti-Myc antibody. $B, C$, Cerebellar neuron cotransfected with Myc-Homer1b and HA-mGluR5. B, Myc immunolabeling; $C$, HA immunolabeling in the same neuron as in $B . D-F$, Same legend as in $A-C$, respectively, but with epitope-tagged Homer1a.

acterized for not interacting with Homer proteins (Tu et al., 1998), a mutant deleted of its C-terminal domain (mGluR5 $\Delta$ ), the P1125E and F1128R mutants, remained in the soma even when coexpressed with Homer1 proteins (Table 1, Fig. $3 A, B, D, E$ ). Also, the absence of mGluR5 mutant immunostaining in the neurites did not result from a lower expression level of the protein. Indeed similar levels of epitope-tagged mGluR5 immunofluorescence were found in the soma of these neurons (mean \pm SD relative fluorescence density $=$ $101 \pm 2 ; n=10)$ and those cotransfected with wild-type mGluR5 and Homer1a or b (see here above values of relative fluorescence density). In contrast to these mutants, the mGluR5 P1127A mutant, which still interacts with Homer1 (Tu et al., 1998), was found in neurites when coexpressed with Homer1a (28 of 28 cells examined; Fig. $3 C$ ). These data indicated that a direct interaction between recombinant Homer1a and mGluR5 was required for localization of mGluR5 in the neurites.

\section{Localization of mGluR5 in the dendrites, but not axons, required the presence of Homer1b}

In 2-week-old cerebellar cultures, when synaptic differentiation and full polarization of granule cells were completed (Van-Vliet et al., 1989), most of the neurons transfected with GFP displayed two neuritic fluorescent processes originating from the cell body (mean $\pm \mathrm{SD}=2.15 \pm 0.14 ; n=30$; Fig. $1 H$ ). In neurons transfected with Myc-Homer1b, alone or in combination with HAmGluR5, only one of the two neurites was Myc- (Fig. $2 A$ ), and both Myc- and HA-immunoreactive, respectively $(1.17 \pm 0.10 ; n=30$; Fig. $2 B, C)$. In the cotransfected neurons, the HA immunolabeling was colocalized with the somatodendritic marker MAP-2 (30 of 30 neurites; Fig. $4 A-C$ ), but not with the axonal marker Tau-1 (0 of 30 neurites; Fig. 4D-F). Myc-Homer1b transfected alone also colocalized with MAP-2, but not Tau-1 (data not shown). These results indicated that Homer1b transfected alone, or mGluR5 cotransfected with Homer1b, were localized in both cell bodies and dendrites, but not axons of cultured cerebellar granule cells.

We then examined whether the mGluR5-Homer1b dendritic clusters aggregated at synaptic sites. Consistent with this hypothesis, in cerebellar granule cells cotransfected with HA-mGluR5 

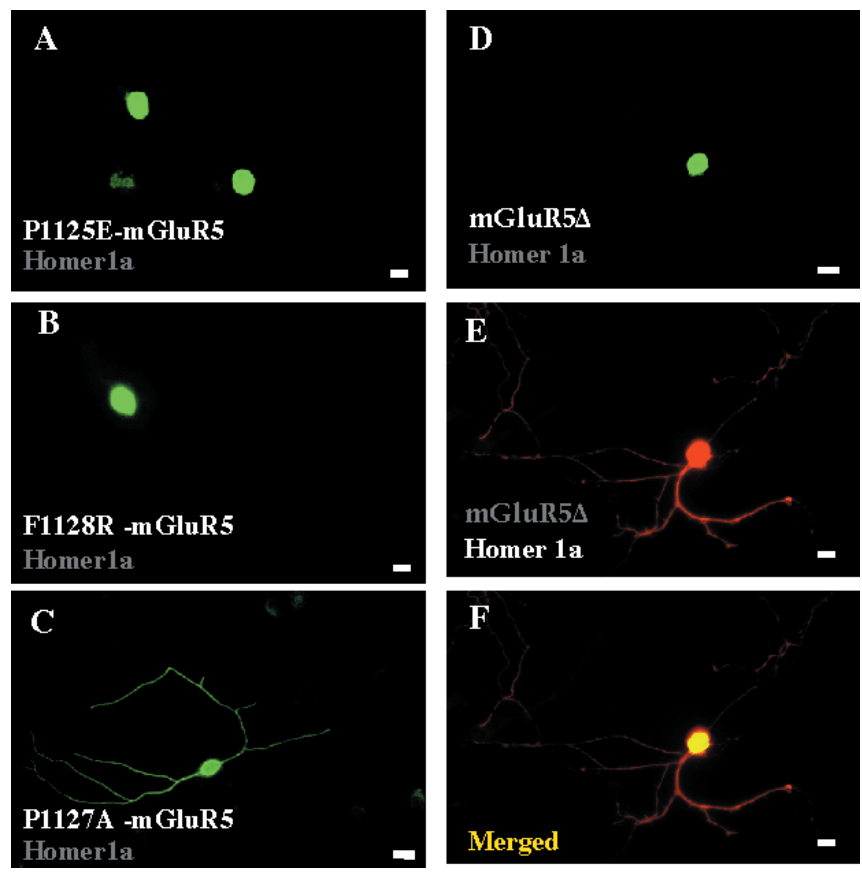

Figure 3. Interaction between Homer1a and mGluR5 is required for neuritic localization of mGluR5 in cultured cerebellar granule cells. Cerebellar neurons were cotransfected with Homerla (wild-type in $A, B$; Myc-tagged in $C-E$ ) and the indicated HA-mGluR5 mutants. $A-D$, HA immunolabeling. $E$, Myc immunolabeling in the same neuron as in $D . F$, Merged panels $D$ and $E$.

and Myc-Homer1b, the dendritic punctate pattern of HA immunostaining colocalized with the selective synaptic marker synaptophysin (40 of 40 neurites; Fig. $4 G-I$ ).

\section{Localization of mGluR5 in both axons and dendrites required the presence of Homer1a}

Cultured cerebellar granule cells transfected with Myc-Homer1a, alone or in combination with HA-mGluR5, displayed both Myc and $\mathrm{HA}$ immunolabeling in more than one neurite originating from a same cell body (mean $\pm \mathrm{SD}=2.1 \pm 0.12 ; n=30$; Fig. $2 D-F$ ). We found HA immunolabeling in both MAP-2 (Fig. 4J-L) and Tau-1 (Fig. 4M-O) and positive processes. In neurons transfected with Myc-Homer1a alone, the Myc immunolabeling also colocalized with both MAP-2 and Tau-1 (data not shown). This indicated that Homer1a allowed the localization of mGluR5 not only in dendrites, but also in axons.

\section{Depolarization-induced expression of endogenous Homer1a and neuritic localization of recombinant mGluR5}

A transient peak of expression of Homer1a mRNA is observed in the hippocampus of adult rats within $1 \mathrm{hr}$ after induction of electroconvulsive seizures, and protein immunostaining in the cortex markedly increases $4 \mathrm{hr}$ after these seizures (Brakeman et al., 1997; Kato et al., 1997). Accordingly, $1 \mathrm{hr}$ depolarization of cultured cerebellar granule cells with either TEA and 4-AP or KA and NMDA induced, $12 \mathrm{hr}$ later, expression of an anti-Homer1immunoreactive protein with a molecular weight close to $30 \mathrm{kDa}$ (Fig. $5 A$ ), as expected for the Homer1a protein. Immunofluorescence experiments indicated that $90 \%$ of treated cerebellar granule cells displayed Homer1 immunoreactivity (Fig. 5C) in both soma and neurites (Fig. 5D). As observed in situ (Brakeman et al., 1997), the Homer1a expression disappeared $2 \mathrm{~d}$ after induction (Fig. 5E). These results showed that sustained depolarization of cultured cerebellar granule neurons induced expression of the endogenous IEG, Homer1a.
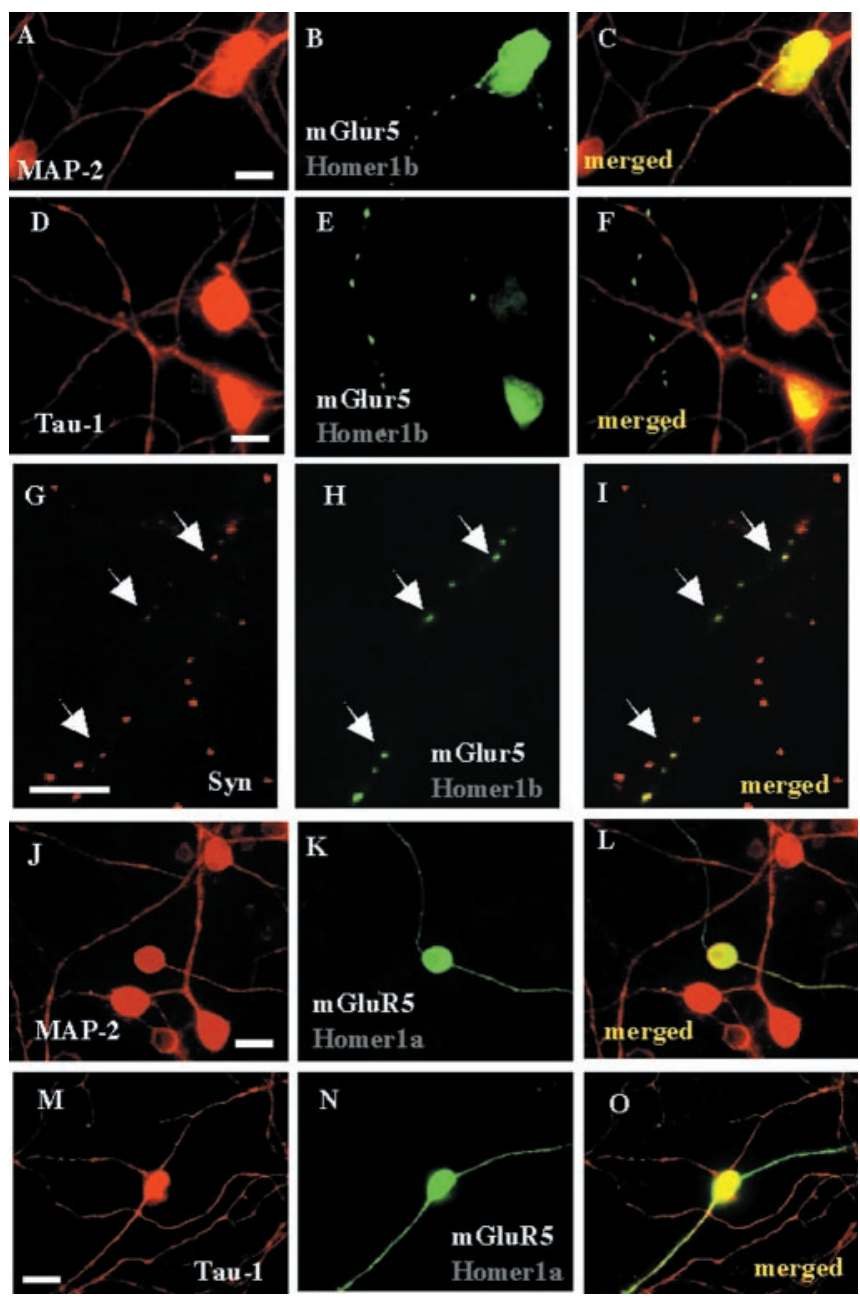

Figure 4. Axon-dendrite localization of mGluR5 in the presence of Homer1a or Homer1b, in cultured cerebellar granule cells. $A-C$, A 2-weekold cerebellar granule cell culture, previously cotransfected with Homer1b and HA-mGluR5, was co-immunolabeled with anti-MAP-2 $(A)$ and anti-HA $(B)$ antibodies. $C$, Merged panels $A$ and $B$. Note the presence of same HA- and MAP-2-immunoreactive neurite. $D-F$, Same legend as in $A-C$, but with anti-tau-1 antibody. Note the presence of HAimmunoreactive, but tau-1-negative neurite. $G-I$, Same culture as in $A-F$ but co-immunolabeled with anti-synaptophysin $(G)$ and anti-HA $(H)$ antibodies. I, Merged panels $G$ and $H$. Note the colocalization of HAmGluR5 and synaptophysin clusters (arrows). Same size calibration as for $A-F$. Scale bars, $10 \mu \mathrm{m}$. $J-L, M-O$, Similar legend as in $A-C$, but in cerebellar neurons cotransfected with Homer 1a and HA-mGluR5. Arrows indicate HA, but not MAP-2 $(J-L)$ or tau-1 $(M-O)$ immunoreactive neurites. Note the presence of HA-mGluR5 in both MAP-2 $(K, L)$ and tau-1 $(N, O)$ immunoreactive neurites.

One, two, and four days after the depolarizing treatments, cerebellar granule cells previously transfected with HA-mGluR5 displayed HA immunostaining in both cell bodies and neurites (Table 1, Fig. $6 B-D)$. In contrast, HA immunoreactivity was exclusively found in cell bodies of treated granule cells previously transfected with the Homer-noninteracting HA-mGluR5 F1128R mutant, (37 of 38 neurons, data not shown). These results indicated that depolarization-induced expression of endogenous Homer1a in cultured neurons triggered a neuritic localization of mGluR5. Interestingly, 2 and even $4 \mathrm{~d}$ after the drug treatment, cerebellar neurons were no longer immunoreactive to the Homer1 antibody (Fig. $5 E$ ) but still displayed neuritic HA-mGluR5 immunostaining (Fig. $6 C, D)$.

\section{DISCUSSION}

The present study reveals a new role for Homer1 proteins: the control of mGluR5 localization in specific neuronal compartments. As summarized in Figure 7, in the absence of Homer1b/c proteins 


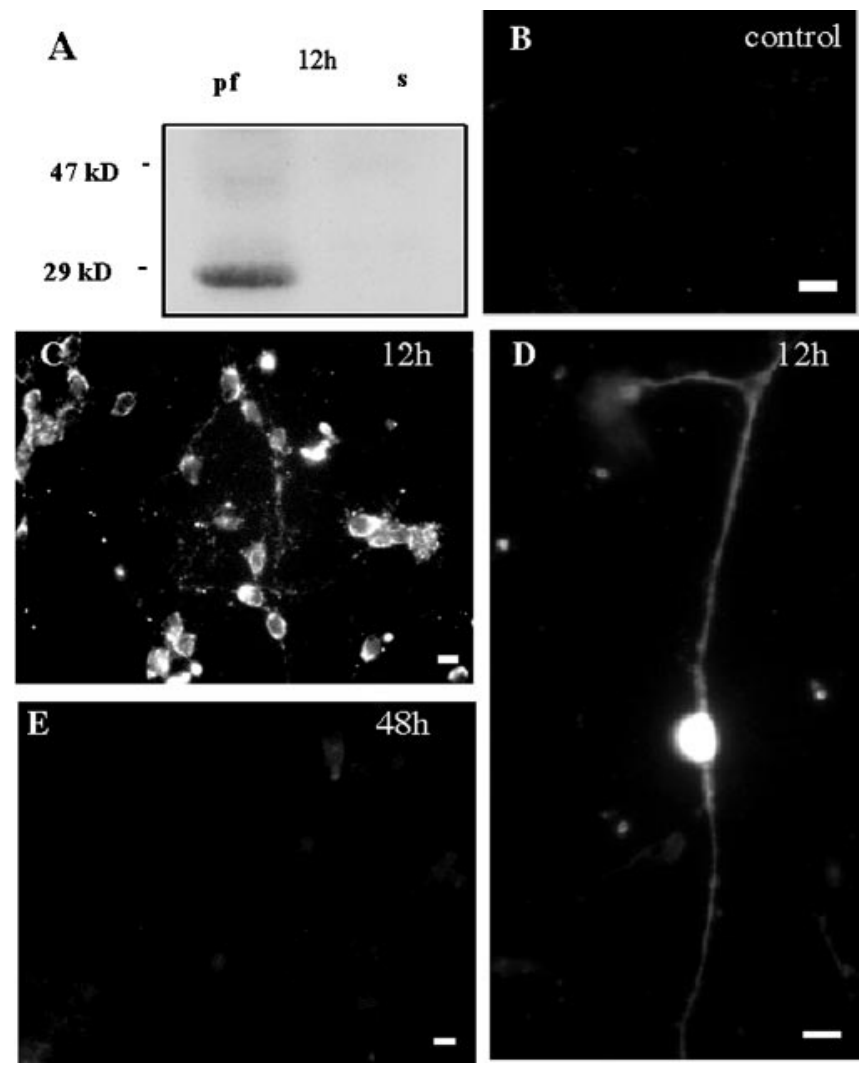

Figure 5. NMDA + kainate-induced transient expression of the immediate early gene product Homerla in cultured cerebellar granule cells. $A$, Western blot obtained with an anti-Homer1 antibody, $12 \mathrm{hr}$ after an NMDA + KA treatment. Note the presence of Homerla protein $(29 \mathrm{kDa}$ band). $B-E$, Cerebellar cultures exposed to drug-free $(B)$ or NMDA $(100 \mu \mathrm{M})+$ kainate KA $(100 \mu \mathrm{M})$-containing culture medium $(C-E)$ and labeled $12 \mathrm{hr}(B-D)$ or $48 \mathrm{hr}(E)$ later with the same anti-Homer1 antibody as in $A$. Note the absence of Homer1-immunoreactive neurons after $48 \mathrm{hr}(E)$. Similar results were obtained with a TEA $(20 \mathrm{~mm})+4-\mathrm{AP}(20 \mathrm{~mm})$ treatment.

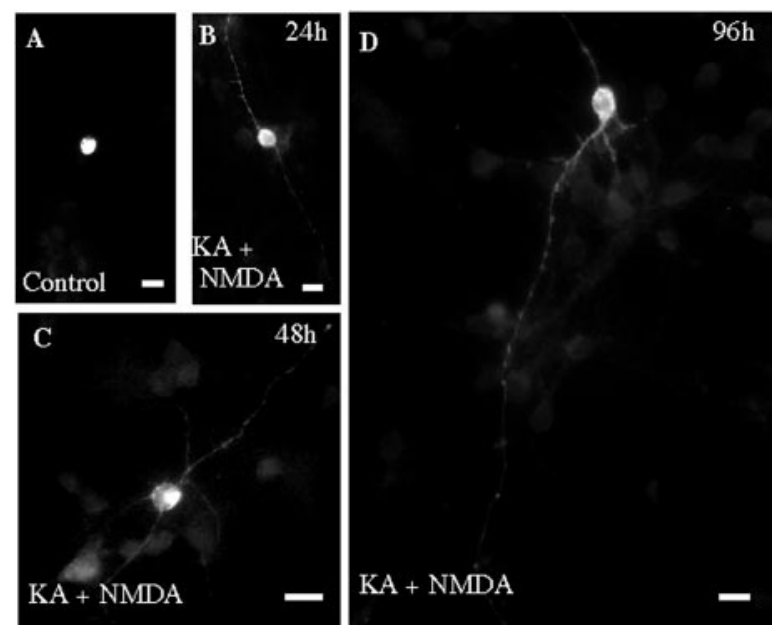

Figure 6. Induction of Homer1a triggers localization of mGluR5 in the neurites of cultured cerebellar granule cells. Cerebellar cultures transfected with HA-mGluR5 were either exposed to drug-free $(A)$ or NDMA + KA-containing culture medium $(B-D)$ and immunolabeled with an anti-HA antibody. $B-D$ were obtained 1,2 , and $4 \mathrm{~d}$ after the drug treatment, respectively. Note neuritic HA immunoreactivity in neurites of treated cultures $(B-D)$.

recombinant mGluR5 was exclusively localized in the soma (Fig. $7 A$ ), whereas in the presence of Homer1b/c proteins the receptor was mostly clustered at dendritic synaptic sites (Fig. $7 B$ ). In the presence of the inducible variant, Homer1a, mGluR5 was found in
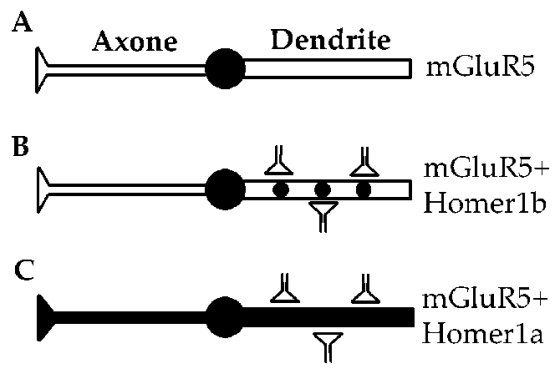

Figure 7. Model for neuritic targeting of mGluR5 by Homer1 proteins. $A$, In the absence of Homer1, mGluR 5 remains in the soma. $B$, Homer1b allows translocation and clustering of mGluR 5 at dendritic synaptic sites. $C$, Induction of Homer1a expression triggers translocation of mGluR5 to both dendrites and axons.

both dendrites and axons (Fig. 7C). Finally, the neuritic localization of mGluR5 observed after induction of endogenous Homer1a let us to anticipate that in natural systems this IEG triggers mGluR5 localization in neuritic processes in response to synaptic input. This may have important consequences for the tune regulation of glutamatergic synapses.

Our cultured cerebellar granule cells do not virtually express native mGluR5 mRNA (Prézeau et al., 1994) and protein (our unpublished observation). This was consistent with in situ immunocytochemistry studies showing a small fraction of mGluR5immunopositive cerebellar granule cells, but rather higher proportion of immunopositive Golgi cells, in the adult cerebellum (Negyessy et al., 1997; Yamagushi and Nakanishi, 1998; Tadokoro et al., 1999). We also found weak expression of Homer2 in our cultured cerebellar granule cells, which contrasted with other findings reporting the presence of this protein in the same type of preparation (Shiraishi et al., 1999). This discrepancy may result from the major differences that existed between our and these authors' culture conditions. Nevertheless, it is worth noting that the same authors also described a sharp decline in the Homer2a immunoreactivity in cerebellar granule cells, in culture after $7 \mathrm{~d}$ in vitro, and in situ in newborn animals after postnatal day 7 .

Because our cultured cerebellar granule cells did not express endogenous Homer1 or endogenous mGluR5, this preparation may be taken here only as a model of polarized cell to study the role of these proteins in neurons. However, based on previous studies showing functional membrane expression of mGluR5 in cultured cerebellar granule cells (Ango et al., 1999), we will tentatively assume that transfected mGluR5 was correctly folded and targeted to the cell surface. Thus, cultured cerebellar granule cells offered a more physiological environment than classical non-neuronal expression systems and were thus preferred to any of these other systems. This was particularly obvious for studies of dendritic/ axonal versus somatic localization of mGluR5. Also, the absence of endogenous Homer1a allowed us to examine the effects of induced endogenous expression of this protein. The following observations also support the possible physiological significance of our results. First, in cultured cortical neurons, Homer1c caused an increase in the dendritic trafficking of mGluR1a (Ciruela et al., 2000). This was consistent with the Homer1b/c-induced dendritic localization of mGluR5 that we observed in cultured cerebellar granule cells. Second, in in situ adult cerebellar Purkinje cells, a mGluR1 construct, which probably lacked of interaction with Homer because the last four transmembrane helices and $\mathrm{C}$-terminal region were replaced by a lacZ unit, was no longer transported to the dendrites and accumulated in the soma (Conquet et al., 1994).

Although our transfection method did not allow us to control the level of expression of the recombinant mGluR5 protein, it was unlikely that its specific distribution observed in the absence or presence of Homer $1 \mathrm{a} / \mathrm{b} / \mathrm{c}$ resulted from overexpression and missorting of the receptor. First, immunofluorescence measurements indicated similar levels of somatic expression of the recombinant receptor, whenever it was expressed alone or in the presence of 
Homer1 proteins. Second, both recombinant and endogenous Homer1a enabled similar neuritic localization of mGluR5a. Third, restricted somatic expression of an mGluR5a mutant that no longer interacted with Homer proteins was observed in the absence and presence of Homer1. Fourth, mGluR5a immunostaining was observed in the neurites of striatal neurons, even in the absence of recombinant Homer1 (but presence of endogenous Homer1b/c).

When transfected alone, recombinant mGluR5 was localized exclusively in the soma of cultured cerebellar granule cells. At least three hypotheses can be proposed to explain this observation. A first one is that the mGluR5 protein contains a soma retention signal. Our experiments with truncated mGluR5 protein $(\mathrm{mGluR} 5 \Delta)$ suggested that this retention signal would be located upstream to the last $285 \mathrm{C}$-terminal residues. This also ruled out the possibility that the endogenous Homer3 protein was responsible for mGluR5 retention in the cell body. A second hypothesis is that in the absence of targeting proteins, recombinant mGluR5 remains in the cell body, as it is the case for other transmembrane receptors in Caenorhabditis elegans neurons (Dwyer et al., 1998; Rongo and Kaplan, 1999). A third hypothesis is that the receptor was transported to the neurites and rapidly degraded because of the absence of metabolic stabilization. This effect would be analog to the one of rapsyn on nicotinic receptors (Wang et al., 1999).

It is important to note that Homer $1 \mathrm{a} / \mathrm{b} / \mathrm{c}$ proteins transfected alone displayed differential axon-dendrite distributions in cultured cerebellar granule cells: Homer1a was localized in both dendrites and axons, whereas Homer1b/c were localized in dendrites solely. This suggested that Homer1a and Homer1b/c contain specific sorting signals: a nonselective neuritic targeting signal in Homer1a, and a dominant axon exclusion signal in Homer1b/c. Homer1a and Homer1b/c share a common EVH1-like domain, and Homer1b/c displays a specific $\mathrm{C}$-terminal domain. One can therefore propose that this $\mathrm{C}$-terminal domain may contain an axon exclusion signal.

When cotransfected with Homer1a/b/c, recombinant mGluR5 displayed axon - dendrite-specific localization, identical to the one of these Homer1 variants transfected alone (i.e., axonal and dendritic with Homer1a vs strictly dendritic with Homer1b/c). This suggests that Homer1 proteins may function as cargo and/or stabilization proteins. Because we found that the proper axon/dendrite localization of mGluR5 required interaction between Homer1 proteins and the receptor, a simple hypothesis is that Homer1 proteins interacted with mGluR5 and then proteins were transported to axon and/or dendrites thanks to specific Homer1 neuritic sorting signals. The presence of Homer1-mGluR5 dendritic clusters in our cultures was consistent with the observation that glutamate receptors are transported to dendritic domains as clusters associated with specialized organelles in fusiform cells of the cochlear nucleus (Rubio and Wenthold, 1999). A second hypothesis would be that mGluR5 was targeted to neurites and metabolically stabilized after interaction with Homer1b in dendrites and Homer1a in dendrites and axons. However, this hypothesis does not apply to Homer1a because mGluR5 was still present in the neurites of cerebellar granule cells even $4 \mathrm{~d}$ after induction of endogenous Homer1a, thus at a period when this IEG could no longer be detected. This result indicated that once mGluR5 has moved to the neurites together with Homerla, its stabilization within this compartment probably resulted from additional factors different from Homer1a. The same conclusion also applies to Homer1b/c because cultured cerebellar granule cells do not naturally express these proteins. We therefore conclude that Homer1a contains a specific targeting signal that promotes trafficking of mGluR5 from the cell body to the neurites. Similarly, a dendrite targeting signal may also be present in Homer1b/c. However, because of more complex interactions between Homer1b/c and other synaptic proteins (Tu et al., 1999), Homer1b/c may have additional roles such as stabilization of mGluR5 at synaptic sites.

As mentioned above, cerebellar granule cells were chosen here as a model to study mGluR5 and Homer1 targeting because they do not express detectable amounts of these two proteins (Prézeau et al., 1994; present study). However, these neurons are known to express native mGluR1a. Accordingly, transfected mGluR1a, as well as a mGluR5/mGluR1a chimeric receptor in which the C terminus of mGluR5 has been replaced by the one of mGluR1a, were found in neuronal processes of cultured cerebellar granule cells, even in the absence of cotransfected Homer1 (data not shown). These observations suggest that although both mGluR5 and mGluR1a interact with Homer proteins, Homer1 is not required for the targeting of mGluR1a to neuronal processes. Therefore mGluR1a and mGluR5 can mobilize different targeting mechanisms in cerebellar granule cells, although the $\mathrm{C}$-terminal tails of both receptors play a critical role in axon-dendrite targeting (Stowell and Craig, 1999; present study). Interestingly, in situ hybridization studies show that localization of Homer1b/c in the murine brain (Xiao et al., 1998) overlaps with the one of mGluR5 (Abe et al., 1992), but not necessarily with the one of mGluR1a (Fotuhi et al., 1993).

Metabotropic GluR5 formed clusters when cotransfected with Homer1b/c, but not when transfected alone or with Homer1a. These results suggested that a mGluR5-Homer dimer assembly was required for this clustering to occur. This was consistent with the essential role of Homer1c C terminus in clustering mGluR1a and mGluR5 in transfected COS-7 cells (Tadokoro et al., 1999) and the immunoprecipitation of Homer1b/c-mGuR5 complexes in extracts prepared from several structures of the brain, including cerebellum (Xiao et al., 1998), but was in contrast with the segregated immunostainings of endogenous mGluR5 and Homer1c in adult cerebellum (Tadokoro et al., 1999). Because Homer1b/c did not cluster when transfected alone, a third partner may be required to crosslink mGluR5-Homer1b/c complexes together. Shank (Naisbitt et al., 1999) is a likely candidate, because this scaffold protein has been shown to trigger the clustering of mGluR5 with Homer1b in COS-7 cells. Indeed, Shank directly interacts with the EVH1 domain of Homer1 proteins, allowing Homer dimers to attach mGluR5 to the GKAP/PSD-95 postsynaptic complexes (Tu et al., 1999). Therefore, direct interaction between mGluR5, Homer1b/c, and Shank proteins may be involved in the clustering of mGluR5 at synaptic sites, in cultured cerebellar granule cells. This was consistent with the enriched localization of native Homer1 dimers at postsynaptic sites (Xiao et al., 1998; Tadokoro et al., 1999).

The present study supports a model in which the constitutively expressed proteins, Homer1b/c, would target mGluR5 to dendritic synaptic sites (Fig. 7B). After intense depolarization, the IEG product, Homer1a, would promote additional mGluR5 expression in both axons and dendrites (Fig. 7C) The presence of presynaptic mGluR5 in the brain remains controversial (Manzoni and Bockaert, 1995; Romano et al., 1995; Lujan et al., 1996; Shigemoto et al., 1997; Herrero et al., 1998; Rodriguez-Moreno et al., 1998), but the present results with those showing that group I mGluR agonistinduced presynaptic action was still present in mGluR1 knock-out (KO) mice (Conquet et al., 1994; Sistiaga et al., 1998), but not in mGluR5 KO mice (Lu et al., 1997), support this hypothesis.

In conclusion, our results provide the first evidence for a role in the targeting of transmembrane receptors by an IEG in neurons, and thus new insight into one of the central questions in understanding IEG functions. Assuming that this might occur in bursting neurons, neuronal activity could thus dynamically regulate mGluR5 distribution. This should provide some form of subcellular memory trace that may participate in remodeling glutamatergic synapses during brain development, synaptic plasticity, or even development of epileptic foci.

\section{REFERENCES}

Abe T, Sugihara H, Nawa H, Shigemoto R, Mizuno N, Nakanishi S (1992) Molecular characterization of a novel metabotropic glutamate receptor mGluR5 coupled to inositol phosphate/ $\mathrm{Ca}^{2+}$ signal transduction. J Biol Chem 267:13361-13368.

Aiba A, Kano M, Chen C, Stanton ME, Fox GD, Herrup K, Zwingman TA, Tonegawa S (1994) Deficient cerebellar long-term depression and impaired motor learning in mGluR1 mutant mice. Cell 79:377-388.

Alagarsamy S, Marino MJ, Rouse ST, Gereau RW, Heinemann SF, Conn PJ (1999) Activation of NMDA receptors reverses desensitization of mGluR5 in native and recombinant systems. Nat Neurosci 2:234-240. 
Ango F, Albani-Torregrossa S, Joly C, Robbe D, Michel JM, Pin JP, Bockaert J, Fagni L (1999) A simple method to transfer plasmid DNA into neuronal primary cultures: functional expression of the mGlu5 receptor in cerebellar granule cells. Neuropharmacology 38:793-803.

Anwyl R (1999) Metabotropic glutamate receptors: electrophysiologica properties and role in plasticity. Brain Res Rev 29:83-120.

Baude A, Nusser Z, Roberts JD, Mulvihill E, McIlhinney RA, Somogyi P (1993) The metabotropic glutamate receptor (mGluR1 alpha) is concentrated at perisynaptic membrane of neuronal subpopulations as detected by immunogold reaction. Neuron 11:771-787.

Bortolotto ZA, Fitzjohn SM, Collingridge GL (1999) Roles of metabotropic glutamate receptors in LTP and LTD in the hippocampus. Curr Opin Neurobiol 9:299-304.

Brakeman PR, Lanahan AA, O'Brien R, Roche K, Barnes CA, Huganir RL, Worley PF (1997) Homer: a protein that selectively binds metabotropic glutamate receptors. Nature 386:284-288.

Catania MV, Landwehrmeyer GB, Testa CM, Standaert DG, Penney Jr JB, Young AB (1994) Metabotropic glutamate receptors are differentially regulated during development. Neuroscience 61:481-495.

Chavis P, Ango F, Michel JM, Bockaert J, Fagni L (1998) Modulation of big $\mathrm{K}^{+}$channel activity by ryanodine receptors and $\mathrm{L}$-type $\mathrm{Ca}^{2+}$ channels in neurons. Eur J Neurosci 10:2322-2327.

Ciruela F, Soloviev MM, McIlhnney RA (1999) Co-expression of metabotropic glutamate receptor type 1alpha with homer-1a/Vesl-1S increases the cell surface expression of the receptor. Biochem $\mathrm{J}$ 341:795-803.

Ciruela F, Soloviev MM, Chan W-Y, McIlhinney RAJ (2000) Homer-1c/ Vesl-1L modulates the cell surface targeting of metabotropic glutamate receptor type1a: evidence for an anchoring function. Mol Cell Neurosci 15:36-50.

Cochilla AJ, Alford S (1998) Metabotropic glutamate receptor-mediated control of neurotransmitter release. Neuron 20:1007-1016.

Conquet F, Bashir ZI, Davies CH, Daniel H, Ferraguti F, Bordi F, FranzBacon K, Reggiani A, Matarese V, Conde F, Collingridge GL, Crépel F (1994) Motor deficit and impairment of synaptic plasticity in mice lacking mGluR1. Nature 372:237-243.

Dwyer ND, Troemel ER, Sengupta P, Bargmann CI (1998) Odorant receptor localization to olfactory cilia is mediated by ODR-4, a nove membrane-associated protein. Cell 93:455-466.

Fiorillo CD, Williams JT (1998) Glutamate mediates an inhibitory postsynaptic potential in dopamine neurones. Nature 394:78-82.

Fotuhi M, Sharp AH, Glatt CE, Hwang PM, von Krosigk M, Snyder SH, Dawson TM (1993) Differential localization of phosphoinositide-linked metabotropic glutamate receptor (mGluR1) and the inositol 1,4,5trisphosphate receptor in rat brain. J Neurosci 13:2001-2012.

Gereau RW, Conn PJ (1995) Multiple presynaptic metabotropic glutamate receptors modulate excitatory and inhibitory synaptic transmission in hippocampal area CA1. J Neurosci 15:6879-6889.

Herrero I, Miras-Portugal MT, Sánchez-Prieto J (1998) Functional switch from facilitation to inhibition in the control of glutamate release by metabotropic glutamate receptors. J Biol Chem 273:1951-1958.

Kano M, Hashimoto K, Kurihara H, Watanabe M, Inoue Y, Aiba A, Tonegawa S (1997) Persistent multiple climbing fiber innervation of cerebellar Purkinje cells in mice lacking mGluR1. Neuron 18:71-79.

Kato K, Ozawa F, Saitoh Y, Hairi K, Inokuchi K (1997) vesl, a gene encoding VASP/Ena family related protein, is upregulated during seizure, long-term potentiation and synaptogenesis. FEBS Lett 412:183-189.

Kato A, Ozawa F, Saitoh Y, Fukazawa Y, Sugivama H, Inokuchi K (1998) Novel members of Vesl/Homer family of PDZ proteins that bind metabotropic glutamate receptors. J Biol Chem 273:23969-23975.

Lu YM, Jia Z, Janus C, Henderson JT, Gerlai R, Wojtowicz JM, Roder JC (1997) Mice lacking metabotropic glutamate receptor 5 show impaired learning and reduced CA1 long-term potentiation (LTP) but normal CA3 LTP. J Neurosci 17:5196-5205.

Lujan R, Nusser Z, Roberts JD, Shigemoto R, Somogyi P (1996) Perisynaptic location of metabotropic glutamate receptors mGluR1 and mGluR5 on dendrites and dendritic spines in the rat hippocampus. Eur J Neurosci 8:1488-1500.

Manzoni O, Bockaert J (1995) Metabotropic glutamate receptors inhibiting excitatory synapses in the CA1 area of rat hippocampus. Eur J Neurosci 7:2518-2523.

Mary S, Gomeza J, Prézeau L, Bockaert J, Pin J-P (1998) A cluster of basic residues in the carboxy-terminal tail of the short mGluR1 variants impairs their coupling to PLC. J Biol Chem 273:425-432.

Naisbitt S, Kim E, Tu JC, Xiao B, Sala C, Valtschanoff J, Weinberg RJ, Worley PF, Sheng M (1999) Shank, a novel family of postsynaptic density proteins that binds to NMDA receptor/PSD-95/GKAP complex and cortactin. Neuron 23:569-582.

Negyessy L, Vidnyansky Z, Kuhn R, Knopfel T, Gorcs TJ, Hamori J (1997) Light and electron microscopic demonstration of mGluR5 metabotropic glutamate receptor immunoreactive neuronal elements in the rat cerebellar cortex. J Comp Neurol 385:641-650.
Nusser Z, Mulvihill E, Streit P, Somogyi P (1994) Subsynaptic segregation of metabotropic glutamate receptors as revealed by immunogold localization. Neuroscience 61:421-427.

Prézeau L, Carette J, Helpap B, Curry K, Pin J-P, Bockaert J (1994) Pharmacological characterization of metabotropic glutamate receptors in several types of brain cells in primary cultures. Mol Pharmacol 45:570-577.

Roche KW, Tu JC, Petralia RS, Xiao B, Wenthold RJ, Worley PF (1999) Homer $1 \mathrm{~b}$ regulates the trafficking of group I metabotropic glutamate receptors. J Biol Chem 274:25953-25957.

Rodriguez-Moreno A, Sistiaga A, Lerma J, Sanchez-Prieto J (1998) Switch from facilitation to inhibition of excitatory synaptic transmission by group I mGluR desensitization. Neuron 21:1477-1486.

Romano C, Sesma MA, MacDonald C, O'Malley K, van den Pol AN, Olney JW (1995) Distribution of metabotropic glutamate receptor mGluR5 immunoreactivity in rat brain. J Comp Neurol 355:455-469.

Rongo C, Kaplan JM (1999) CaMKII regulates the density of central glutamatergic synapses in vivo. Nature 402:195-199.

Rubio ME, Wenthold RJ (1999) Differential distribution of intracellular glutamate receptors in dendrites. J Neurosci 19:5549-5562.

Ryo Y, Miyawaki A, Furuichi T, Mikoshiba K (1993) Expression of the metabotropic glutamate receptor mGluR1 alpha and the ionotropic glutamate receptor GluR1 in the brain during the postnatal development of normal mouse and in the cerebellum from mutant mice. J Neurosci Res 36:19-32.

Shigemoto R, Kulik A, Roberts JD, Ohishi H, Nusser Z, Kaneko T, Somogyi P (1996) Target-cell-specific concentration of a metabotropic glutamate receptor in the presynaptic active zone. Nature 381:523-525.

Shigemoto R, Kinoshita A, Wada E, Nomura S, Ohishi H, Takada M, Flor PJ, Neki A, Abe T, Nakanishi S, Mizuno N (1997) Differential presynaptic localization of metabotropic glutamate receptor subtypes in the rat hippocampus. J Neurosci 17:7503-7522.

Shiraishi Y, Mitzutani A, Bito H, Fujisawa K, Narumiya S, Mikoshiba K, Furuichi T (1999) Cupidin, an isoform of Homer/Vesl, interacts with the actin cytoskeleton and activated Rho family small GTPases and is expressed in developing mouse cerebellar granule cells. J Neurosci 19:8339-8400.

Sistiaga A, Herrero I, Conquet F, Sanchez-Prieto J (1998) The metabotropic glutamate receptor 1 is not involved in the facilitation of glutamate release in cerebrocortical nerve terminals. Neuropharmacology 37:1485-1492.

Stowell JN, Craig AM (1999) Axon/dendrite targeting of metabotropic glutamate receptors by their cytoplasmic carboxy-terminal domains. Neuron 22:525-536.

Tadokoro S, Tachibara T, Imanaka T, Nishida W, Sobue K (1999) Involvement of unique leucine-zipper motif of PSD-Zip 45 (Homer 1c/Vesl-1L) in group 1 metabotropic glutamate receptor clustering. Proc Natl Acad Sci USA 23:13801-13806.

Tu JC, Xiao B, Yuan JP, Lanahan AA, Leoffert K, Li M, Linden DJ, Worley PF (1998) Homer binds a novel proline-rich motif and links group I metabotropic glutamate receptors with $\mathrm{IP}_{3}$ receptors. Neuron 21:717-726.

Tu JC, Xiao B, Naisbitt S, Yuan JP, Petralia RS, Brakeman P, Doan A, Aakalu VK, Lanahan AA, Sheng M, Worley PF (1999) Coupling of mGluR/Homer and PSD-95 complexes by the Shank family of postsynaptic density proteins. Neuron 23:583-592.

Van den Pol AN, Kogelman L, Ghosh P, Liljelund P, Blackstone C (1994) Developmental regulation of the hypothalamic metabotropic glutamate receptor mGluR1. J Neurosci 14:3816-3834.

Van-Vliet BJ, Sebben M, Dumuis A, Gabrion J, Bockaert J, Pin JP (1989) Endogenous amino acid release from cultured cerebellar neuronal cells: effect of tetanus toxin on glutamate release. J Neurochem 52:1229-1239.

Wang ZZ, Mathias A, Gautam M, Hall ZW (1999) Metabolic stabilization of muscle nicotinic acetylcholine receptor by rapsyn. J Neurosci 19:1998-2007.

Weiss S, Pin J-P, Sebben M, Kemp D, Sladeczek F, Gabrion J, Bockaert J (1986) Synaptogenesis of cultured striatal neurones in serum-free medium: a morphological and biochemical study. Proc Natl Acad Sci USA $83: 2238-2242$

Xiao B, Tu JC, Petralia RS, Yuan JP, Doan A, Breder CD, Ruggiero A, Lanahan AA, Wenthold RJ, Worley PF (1998) Homer regulates the association of group I metabotropic glutamate receptors with multivalent complexes of Homer-related, synaptic proteins. Neuron 21:707-716.

Yamagushi S, Nakanishi S (1998) Regional expression and regulation of alternative forms of mRNAs derived from two distinct transcription initiation sites of the rat mGluR5 gene. J Neurochem 71:60-68.

Yu SP, Sensi SL, Canzoniero LM, Buisson A, Choi DW (1997) Membrane-delimited modulation of NMDA currents by metabotropic glutamate receptor subtypes $1 / 5$ in cultured mouse cortical neurons. J Physiol (Lond) 499:721-732. 